\title{
PROFESSOR WITOLD NOWICKI - THE PROMINENT PATHOLOGIST OF THE FIRST HALF OF THE XX CENTURY ${ }^{1}$
}

\author{
Zerbino D. D., Volos L. I.
}

\section{INTRODUCTION}

The history of Lviv Medical University dates back to 1661, when on January $20^{\text {th }}$, under the privilege of King John Casimir the Jesuit College was elevated to the rank of the Academy with the granted tittle of the University of Four Faculties, but in addition to the royal decree, the creation of the Academy required a parliamentary resolution and the approval of the Pope. Polish Parliament (Sejm) has not agreed, and Pope allowed only for doctoral degrees in theology and philosophy. The Medical Faculty at Lviv University was finally established in 1894. Since then, the world's best specialists and scientists have developed medical science. History of Lviv Medical University is closely related with eminent personalities that had a great impact on the development of medical science. Andrew Obrzut (02.02.1854-29.09.1910) (Figure 1) was a professor of medicine in Prague and Lviv, a student of the founder of the Czech Institute of Pathological Anatomy Jaroslav Hlava. The scientific achievements of A. Obrzut are summarised in unique publications published in German, Polish, French, and Czech language about new research on the pathogenesis of glomerulonephritis, tuberculosis, caseous pneumonia, amyloid degeneration and others. However, the first of all his merits for the readership of Polish and Ukraine pathologists was his a two-volume textbook on Pathological Anatomy and Bacteriology. Professor greatly influenced the development of Pathological Anatomy in Poland, Czechy and Ukraine. Andrew Obrzut remains an outstanding example of a very careful and precise pathologist.

\footnotetext{
${ }^{1}$ We would like to thank the History of Pathology Working Group of the European Society of Pathology and Polish Society of Pathology, namely Professor Ewa IżyckaŚwieszewska, head of the Department of Pathology and Neuropathology of the Medical University Gdansk for selection of our abstracts for the Fifth International Meeting on the History of Pathology held at Gdansk, Poland on June 29-30, 2018 and XXI Congress of Polish Society of Pathology, Lublin, Poland, on September 26-28, 2019. We would like to thank the organizers Polish Society of Pathology, namely Professor Janusz Ryś and Professor Krzysztof Okon, for this initiative of the Society because it helps all doctors to participate in a global scientific meeting and related not only to the history of pathology but also to medicine in general. And we would like to thank the Rector of Danylo Halytsky Lviv National Medical University academician of National Academy of Medical Sciences of Ukraine, Professor Borys Zimenkovsky for his continued support in our creative search.
} 
The outstanding clinical pathologist of the first half of the twentieth century is considered to be Witold Nowicki ${ }^{2,3,4}$ (Figure 2).

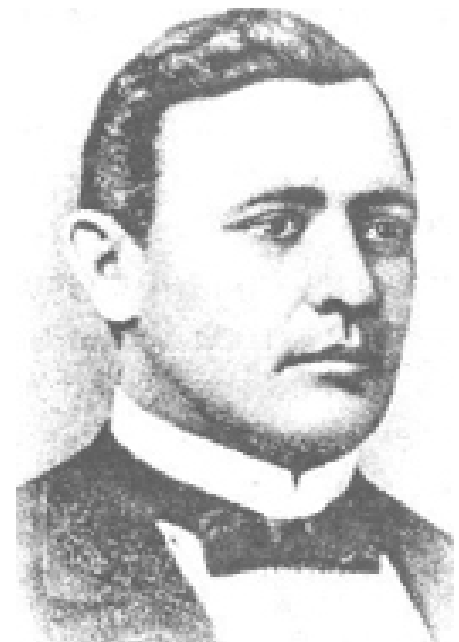

Figure 1. Professor Andrew Obrzut

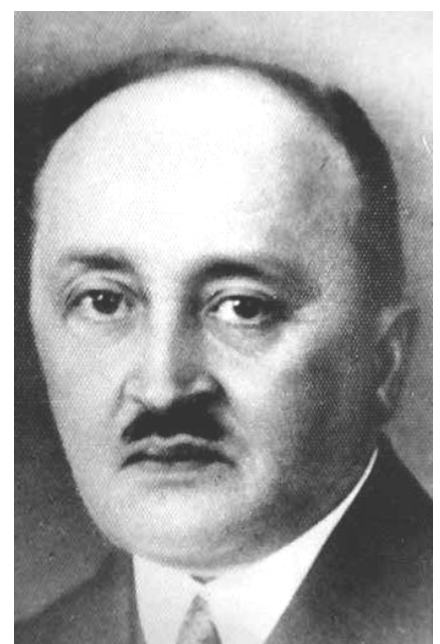

Figure 2. Professor Witold Walerian Nowicki

Nowicki Witold Walerian (18th of July 1878 - 4th of July 1941) - Professor of Medicine in Lviv, pupil of the founder and the first head of the Department of Pathological Anatomy of Lviv University of John Casimir (Polish: Uniwersytet Lwowski Jana Kazimierza) Professor Andrzej Obrzut. Assistant (1902), Assistant Professor (1908), Professor (1913), Head of the Department of Pathological Anatomy (1919-41), Dean of the Faculty of Medicine (1923-24, $1939)^{5,6}$. President of the Lviv Medical Association (1920-21) and the Lviv Cancer Committee, Founder of Lviv University Hygiene Museum (1930), cofounder of Morshyn Resort. Author of the three-volume textbook "Pathological Anatomy” (in Polish: “Anatomia Patologiczna”) and about 90 scientific articles.

${ }^{2}$ Zerbino D.D. Vitold Novitsky is a prominent clinical pathologist of the first half of the twentieth century (on the 100th anniversary of his birth. Archive of Pathology. 1978, No. 10: 77-79.

3 Zerbino D.D., Volos L.I., Ivashchenko V.A. Professor Witold Nowicki - great clinical pathologist of first half of the XX century. Pol J Pathol. 2019; 8-9.

${ }^{4}$ Albert Z. Anatomia patologiczna we Lwowie w XVIII-XX wieku. F Arch Hist Filoz Med 2001; 56(3): 229-251; Language: PL.

${ }^{5}$ Shapiro IYa. Essays on the history of the Lviv Medical Institute. Lviv, LGMI 1959: 150-154 [foto]. [in Russian].

${ }^{6}$ Hahn W. Kronika Uniwersytetu Lwowskiego [Chronicle of Lvov University]. Lvov 1912; 2: 265, 349-350, 455-457. [in Polish]. 


\section{Impact Witold Nowicki on Development of Pathological Anatomy of the first half of XX century}

Witold Walerian Nowicki was born on July 18, 1878 in Bochnia, near Cracow, Poland. He came from a family of intellectuals (Witold's father, Franciszek Nowicki, was the director of a school in Bochnia) ${ }^{7}$. First studied in elementary school in Bochnia, then due to the moved his family from Bochnia, Witold graduated from the last classes of the Grammar School at the prestigious St. Anne’s Gymnasium in Cracow (Figure 3).

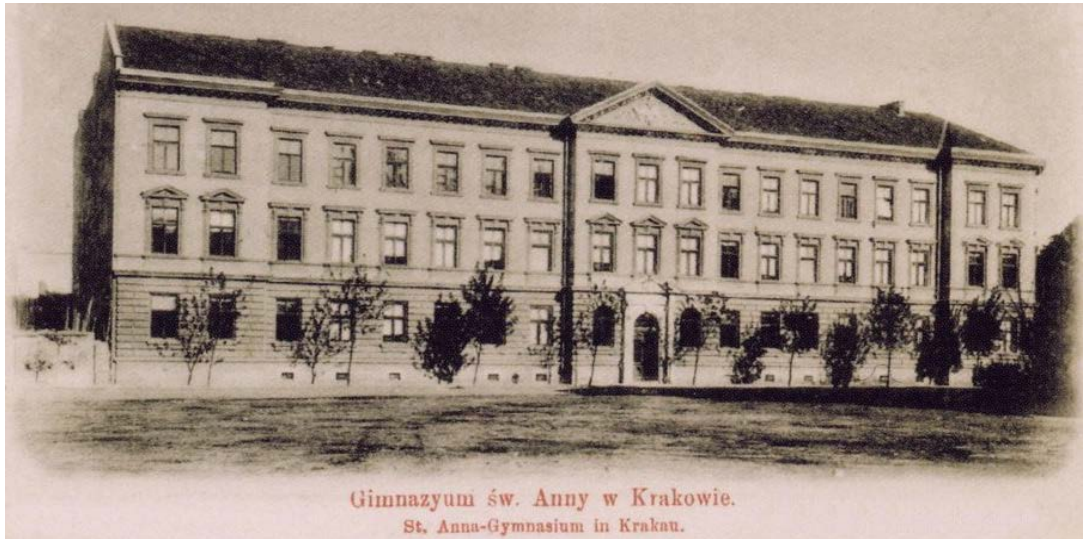

Figure 3. St. Anne’s Gymnasium in Cracow

In 1896-1902, Witold Nowicki studied at the Medical Faculty of Jagiellonian University in Cracow (in Polish: Uniwersytet Jagielloński, Kraków, Polska). He received his medical degree (1902). After obtaining a higher medical education and getting a diploma, Witold Nowicki moved to Lviv, where he received a position of assistant at the Department of Pathological Anatomy of Lviv University (in Polish: Zakład Anatomii Patologicznej) ${ }^{8}$ (Figure 4).

During his work, Witold Nowicki proved himself to be a capable scientist and in 1908 he got the post of associate professor of the Department of Pathological Anatomy. The scientific consultant to the young assistant was Professor Andrzej Obrzut, who was mentioned by Witold Nowicki ${ }^{9}$.

\footnotetext{
${ }^{7}$ Wielka ilustrowana encyklopedia powszechna. Krakow, 1938, Bd. 1-22.

${ }^{8}$ Zwoździak W. Historia Wydziału Lekarskiego Uniwersytetu Lwowskiego [History of the Faculty of Medicine of the Lwów University]. Arch Hist Med (Warsz) 1965; 28: 57-85, 209-28, 309-336. [in Polish]

9 Nowicki W. Andrzej Obrzut. (Wspomnienie pośmiertne) [Andrzej Obrzut. (Obituary)]. Przegl Lek 1910; 49: 600. [in Polish]
} 


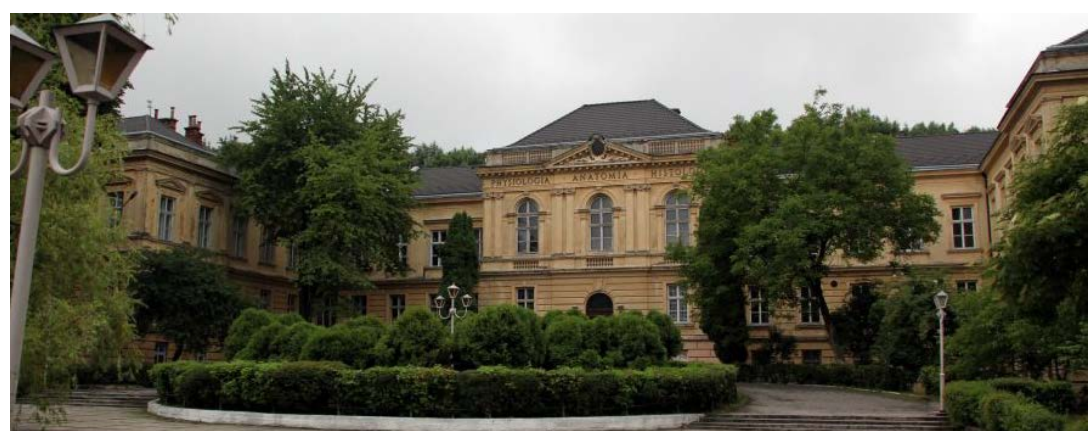

Figure 4. Department of Pathological Anatomy of Lviv University

From 1913 to 1919 Witold Nowicki was Professor, and from 1919 was the Head of the Department of Pathological Anatomy. In 1913, Professor $\mathrm{W}$. Nowicki published a monograph on the study of tuberculosis "The Anatomical Research of the upper hole of the chest and its attitude the upper chest tuberculosis" (in Polish: "Badanie anatomiczne górnego otworu klatki piersiowej and jego związek $\mathrm{z}$ gruźlicą płucną pochodzenia wierzchołkowego", 107 pp., 20 fig.).

In 1914, the work was awarded the Warsaw Medical Society (in Polish: Warszawskie Towarzystwo Lekarskie). Professor Witold Nowicki, a recognized specialist in pathological anatomy and forensic expert with many years of practice, had left a rich scientific heritage - more than 90 scientific works in Polish, German and French. His articles have been stored and are at the Museum of Human Diseases of Danylo Halytsky National Medical University.

W. Nowicki actively worked and published a number of studies on infectious pathology (typhoid and paratyphoid diseases, dysentery, Spanish influenza, skin changes at lichen $)^{10}$. He studied intestinal pneumatosis - a rare disease of the gastrointestinal tract, in which the intestinal gases penetrate into the walls of the organ and form air cavities in it. Most often the pathological process, according to the professor, were localized in the submucosal or subserous layer of the colon or small intestine. The disease had affected people of all ages, but mostly manifested in the elderly due to decrease in physical activity and frequent disorders of the digestive system. The sizes of air cysts were from 0.5 to $5 \mathrm{~cm}$ in diameter ${ }^{11}$.

${ }^{10}$ Nowicki W.O skombinowanem zastosowaniu pośrednich sposobów w badaniu stolców tyfusowych, paratyfusowych i czerwonkowych. Kraków. Reprint from Przegl Lek 1917; 8: 2. [in Polish]

${ }^{11}$ Nowicki W. Ueber chronisch entstehendes Gasblaschenemphysem (Pneumatosis cystoides) [About chronic arising "gas bubble emphysema"]. Virchows Archiv fur pathologie Anatomie und Physiologie und fur klinsche Medizin 1909; 198: 143-182. 
Professor thoroughly examined scleroma, based on large collected section material and described the terminal stages of the disease ${ }^{12}$. The scleroma monograph was published after the war in 1950 in Wroclaw. The macroscopic preparations based on autopsy specimens and collected by Professor W. Nowicki that are in the Museum of Human Diseases (Figure 5).

The professor had also studied oncopathology ${ }^{13}$, including lung cancer ${ }^{14}$ and investigated tuberculosis ${ }^{15}$. For a long time, he studied the pathophysiology of hormonal regulation, the effect of adrenaline on adrenal chromaffin, and kidney morphology ${ }^{16}$. Thus, from 1920 to 1939, W. Nowicki published most of his scientific articles. All of these articles are completely saved and are in the Museum of Human Diseases of the Danylo Halytsky National Medical University.

In 1928 the professor published a textbook "Pathological anatomy textbook for students and doctors. Part I (General Pathology)", which contained a huge database of various pathologies illustrated by over 1200 drawings was done under the personal guidance of $\mathrm{W}$. Nowicki ${ }^{17}$. In 1936, a textbook on pathological anatomy was published in two volumes "Pathological anatomy special textbook for students and doctors" ${ }^{18}$ (Figure 6). Furthermore, he was Dean of the Medical Faculty (1923-24, 1939) of Lviv University. For many years, Professor W. Nowicki was the editor of the journal "Lwowski Tygodnik Lekarski" and "Polską Gazetę Lekarską", and since 1937 had been the chairman of the editorial board of the "Biblioteczki Hygienicznej" - the edition of the

${ }^{12}$ Nowicki W. Obrazy histologiczne twardzieli, szczególnie w jej okresie zejściowym [Histological pictures of scleroma, particularly at its end stage]. Pol Gaz Lek 1933; 12; 696-700. [in Polish]

${ }^{13}$ Nowicki W. Rak - jako zagadnienie w nauce [Cancer as an issue in science]. Pol Gaz Lek 1939; 18: 1-3. [in Polish]

${ }^{14}$ Nowicki W. Sprawa przyrostu raka płuc w świetle materjału sekcyjnego Instytutu Anatomji Patologicznej U. J.K. we Lwowie. [Report of increase in lung cancer cases in autopsy material of Institute of Pathological Anatomy UJK in Lvov]. Pol Gaz Lek 1931; 10: 99. [in Polish]

${ }^{15}$ Nowicki W. Otwór górny klatki piersiowej w świetle badań anatomicznych i stosunek jego gruźlicy płuc pochodzenia szczytowego [Superior apertura of thorax in light of anatomical studies and its relation to apical pulmonary tuberculosis]. Pam Tow Lek 1914; 110: 1-67, 137-175, 259-283. [in Polish]

${ }^{16}$ Nowicki W. Dalsze badania doświadczalne nad stosunkiem nadnercza do nerki [Further experimental studies on relation of suprarenal gland to kidney]. Lwowski Tyg Lek 1910; 5: 439-441. [in Polish]

${ }^{17}$ Nowicki W. Anatomja patologiczna podręcznik do użytku studentów i lekarzy. Część ogólna [Pathological Anatomy: handbook for students and medical doctors. General Part]. Drukarnia Gubrynowicza i syna. Druk W.L. Anczyca i spółki Kraków 1928; 596. [in Polish]

${ }^{18}$ Nowicki W. Anatomja patologiczna szczegółowa. Podręcznik do użytku studentów i lekarzy. Tom II [Systemic Pathological Anatomy. Handbook for students and medical doctors. Volume II]. Polska Akademia Umiejętności, Kraków 1936; 471. [in Polish] 
Hygienic Society, promotion of hygiene in society. In 1930 - he became the founder of the Hygiene Museum of Lviv University.

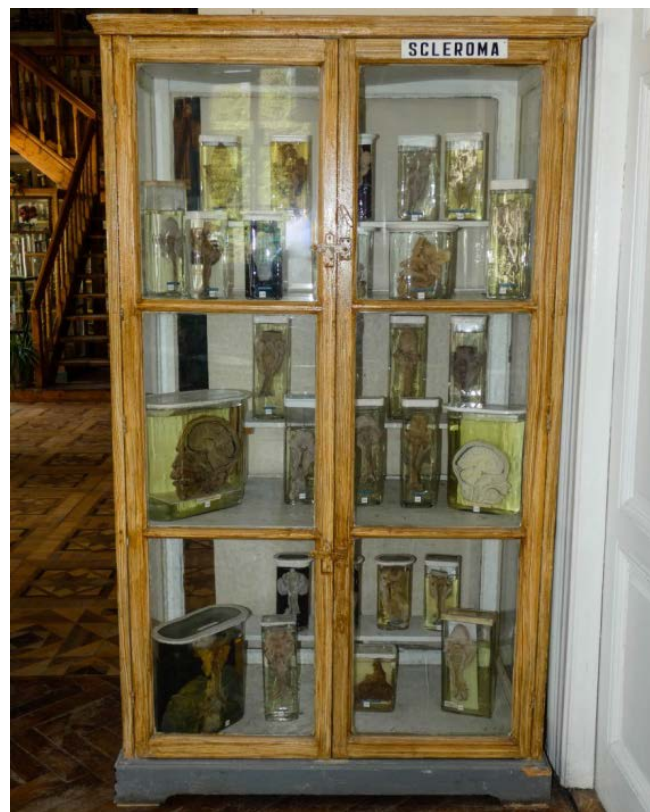

a) Museum of Human Diseases. Macroscopic preparations of scleroma
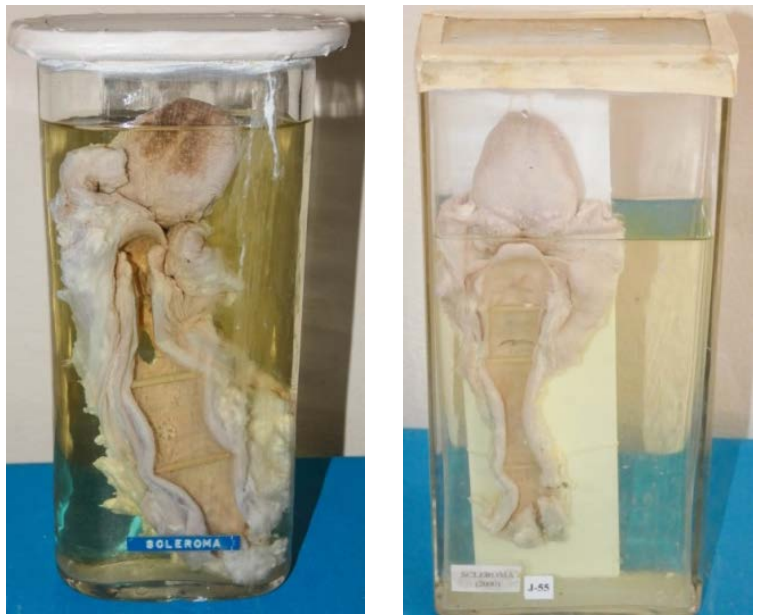

b) Macroscopic preparations of scleroma

Figure 5 


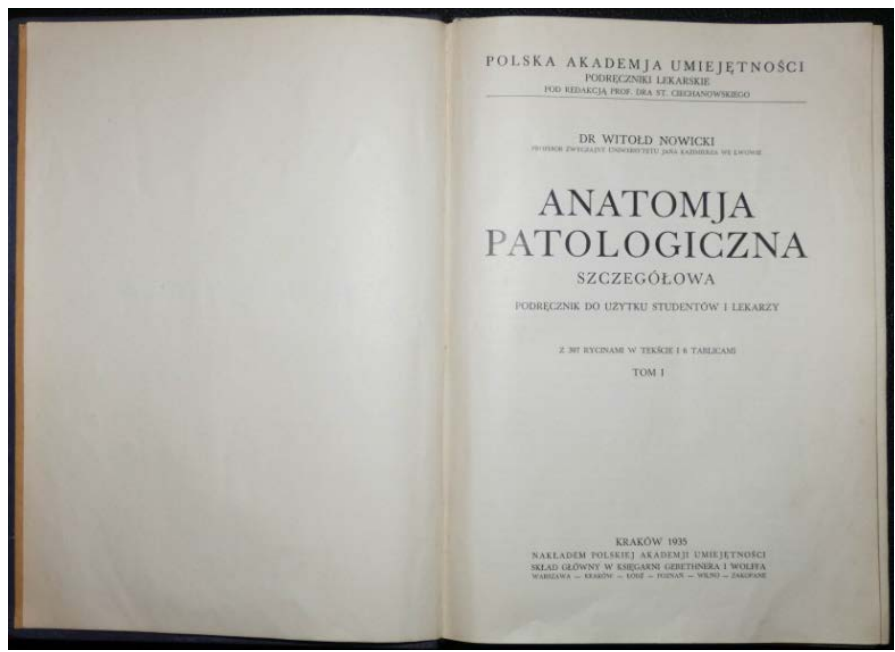

Figure 6. Pathological anatomy textbook for students and doctors. Part I (General Pathology)

\section{Active participation of Professor W. Nowicki in the social life of Lviv physicians}

In addition to academic and scientific activities, Professor W. Nowicki actively participated in the social life of Lviv physicians. In 1937, as head of the Izby Lekarsiej of Lviv, he, together with the Medical Society of Lviv, built and opened the Doctor's House, which became the center of scientific and public life of Lviv physicians. Being the head of the Orphans' and Widows Fund at the Lviv Medical Society, W. Nowicki greatly assisted the widows of doctors and medical students in need, often spending his own money.

He was elected as the president of the Lviv Medical Association (1920 1921) and the Lviv Committee of Fight against Cancer ${ }^{19}$.

Professor W. Nowicki was the co-founder of the Morshyn resort ${ }^{20,21}$ (Figure 7) and professor W. Nowicki was a long-time pathologist of the Lviv State General Hospital and the Hospital for the Mentally patients in Kulpark (Zakładu dla Umysłwo Chorych).

19 Nowicki W, Franke U. W sprawie utworzenia Związku polskich towarzystw lekarskich i wydawania jego naukowego biuletynu [In case of establishment of Polish Medical Societies Association and editio of its scientific bulletin]. Pol Gaz Lek 1925; 4: 26-27. [in Polish]

${ }^{20}$ Nowicki W. Morszyn [Morszyn]. Pol Gaz Lek 1932; 12: 814-815. [in Polish]

${ }^{21}$ Nowicki W. Otwarcie Domu Zdrojowego w Morszynie - Zdroju [Openning of health-resort Centre in Morszyn Spa]. Pol Gaz Lek 1938; 17: 645-648. [in Polish] 

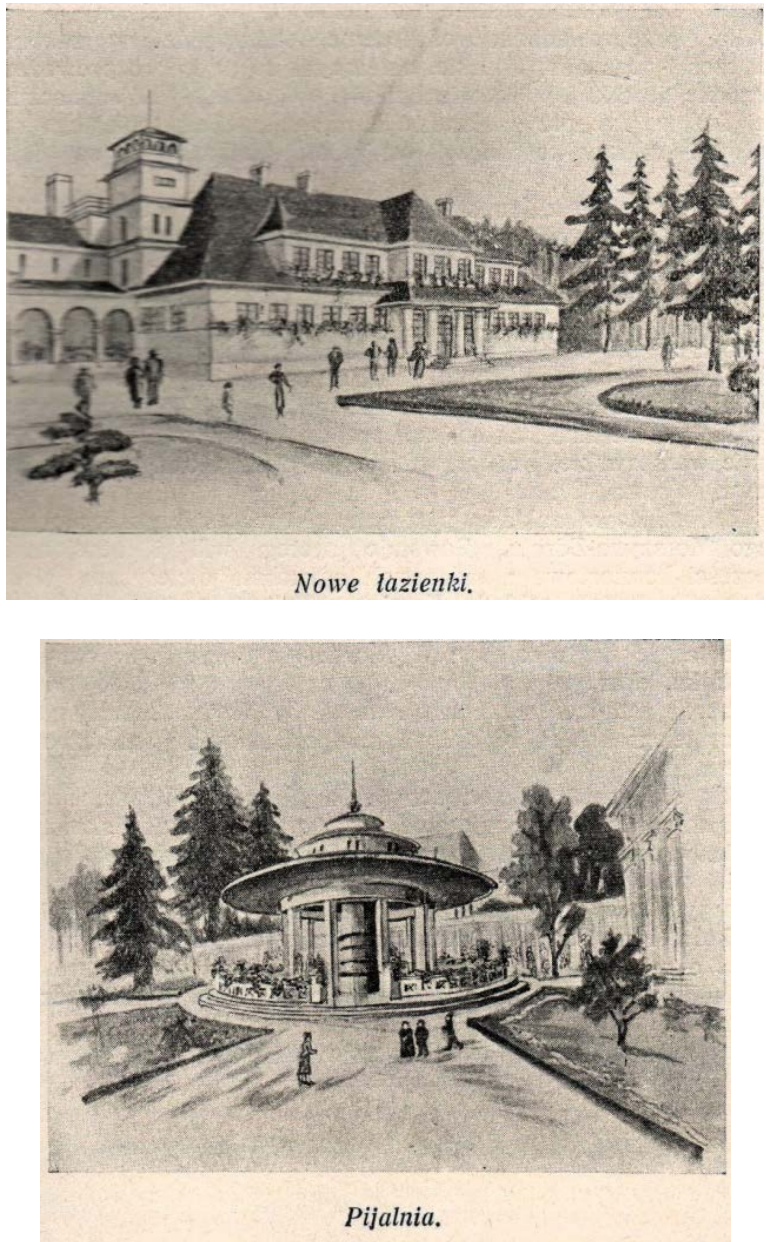

Figure 7. Morshyn resort

There is no doubt that a significant influence on the young pathologist W. Nowicki had Professor Andrew Obrzut. The archives contain protocols of autopsies written by W. Nowicki. The first patho-anatomical autopsy W. Nowicki performed on 15.11.1902, and in 1903 and 1904 he performed 488 and 473 autopsies respectively (from a total of 977 and 1004 autopsies. The protocol of the pathological-anatomical autopsy, written by W. Nowicki himself, is kept in the archive of the Museum (Figure 8). Nowadays, the histological preparations, including unique rare diseases, diagnosed by $\mathrm{W}$. Nowicki, are in perfect condition (Figure 9, 10, 11). 


\section{INSTYTUT PATOLOGICZNO-ANATOMICZNY \\ c. k. Uniwersytetu we Lwowie.}

\begin{tabular}{|c|c|}
\hline sidf & $\begin{array}{l}\text { Protokolu sekeyjnego L. p. } 862 \\
\text { Data sekeyi d Is } \bar{X} \text {. } 190 \varepsilon \text {. }\end{array}$ \\
\hline 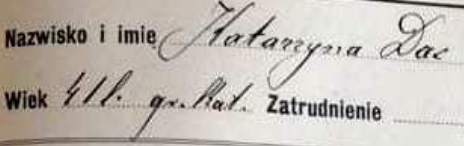 & $\begin{array}{l}\text { Klinika } \\
\text { Oddziat szpitalny } W=\overline{I I}\end{array}$ \\
\hline
\end{tabular}

Rozpoznanie kliniczne:

Onberculoris pulanenmon

Rozpoznanie patologiczno-anatomiczne:

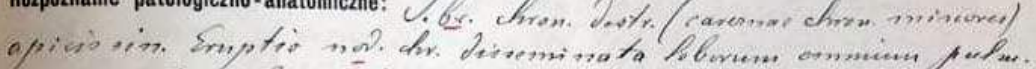

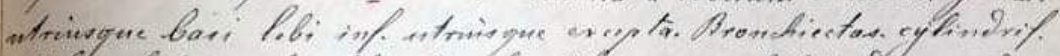

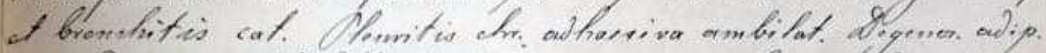

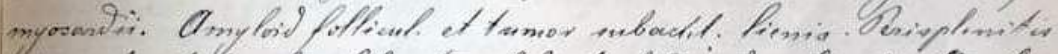

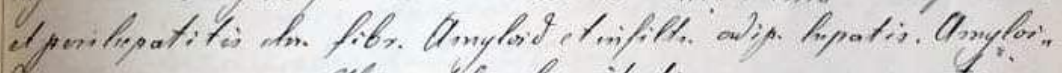

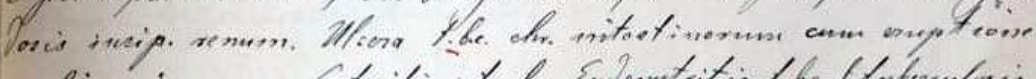

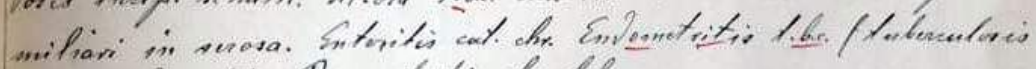

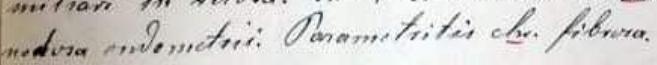

Wynik badania bakteryologicznego:

Wynik badania histologicznego:

Protokól sekeyjny

Figure 8. Protocol of the first pathological-anatomical autopsy 


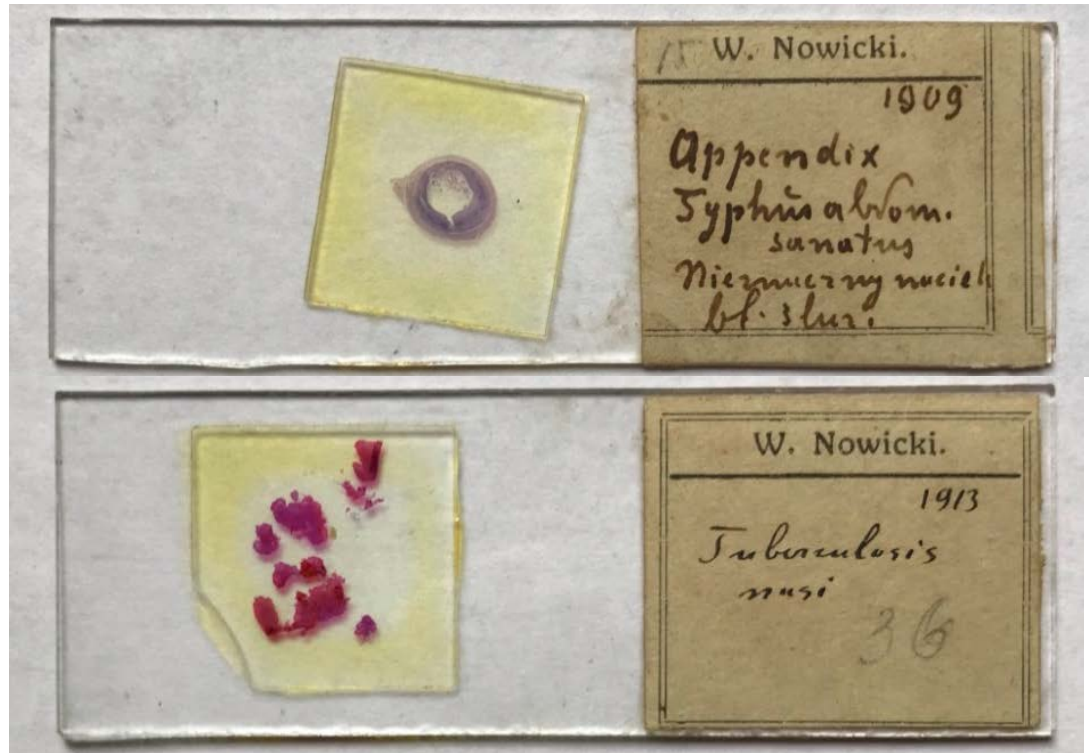

Figure 9. Histological preparation and diagnosis written by W. Nowicki (appendicitis and tuberculosis of nose)
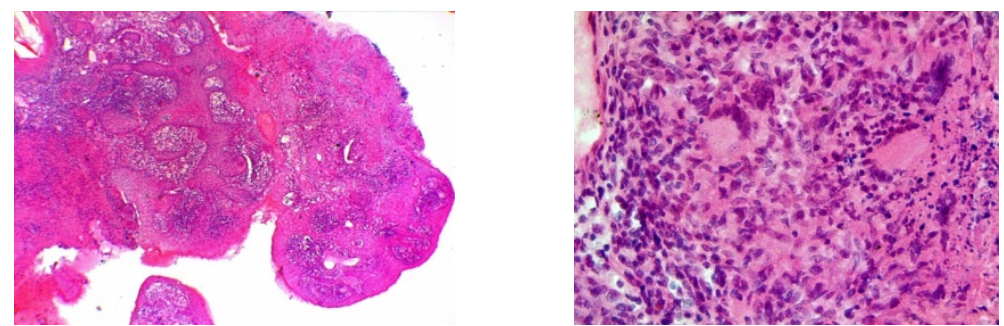

Figure 10. Nasal tuberculosis (granulomas, Pirogov-Langhans cells). Histological preparation of $W$. Nowicki
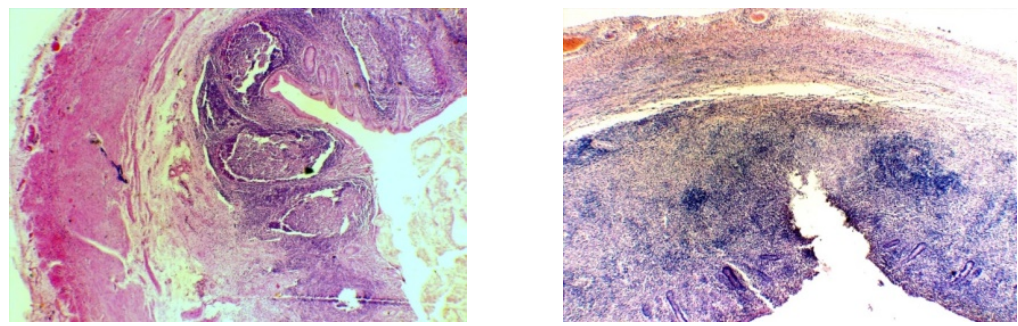

Figure 11. Acute appendicitis. Histological preparation of W. Nowicki 
Professor W. Nowicki scientific achievements are summarized in publications published in Polish, German, and French.

After the reunion of the West Ukrainian lands, Professor W. Nowicki actively took part in public work - in 1940 he was elected as a deputy of the City Council.

During the Second World War at night of July 3 - July 4, 1941 he had been arrested and executed by German invaders on Wuleckie hills and also 41 representatives of the Lviv intelligentsia, including 13 scientists of the Lviv Medical Institute. W. Nowicki was shot dead with his 27-year-old son, Doctor of Science, assistant of the Department of Microbiology Jerzy Nowicki (Figure 12). So tragically the life of a great researcher, pathologist and teacher, who made a definite contribution to the development of pathological anatomy, was cut short ${ }^{22}$. The Monument to those who had been shot in 1941 - to representatives of the Polish intelligentsia, Lviv (Figure 13).

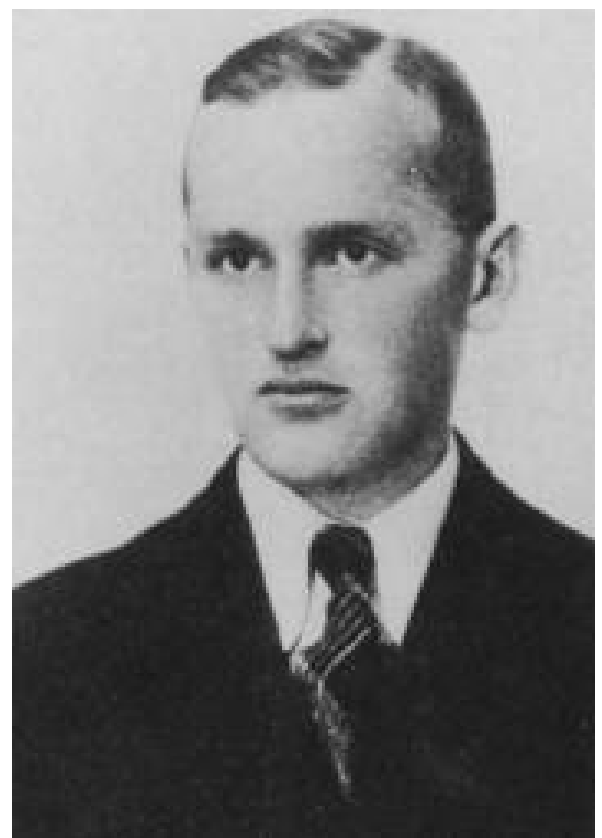

Figure 12. Dr Med Jerzy Nowicki assistant at the Institute of Hygiene, University of John Casimir, son of Prof. Witold Nowicki

${ }^{22}$ Bonusiak W. Kto zabił profesorów lwowskich? [Who killed Lvovian Professors?] 1st ed. Krajowa Agencja Wydawnicza, Rzeszów 1989. [in Polish] 


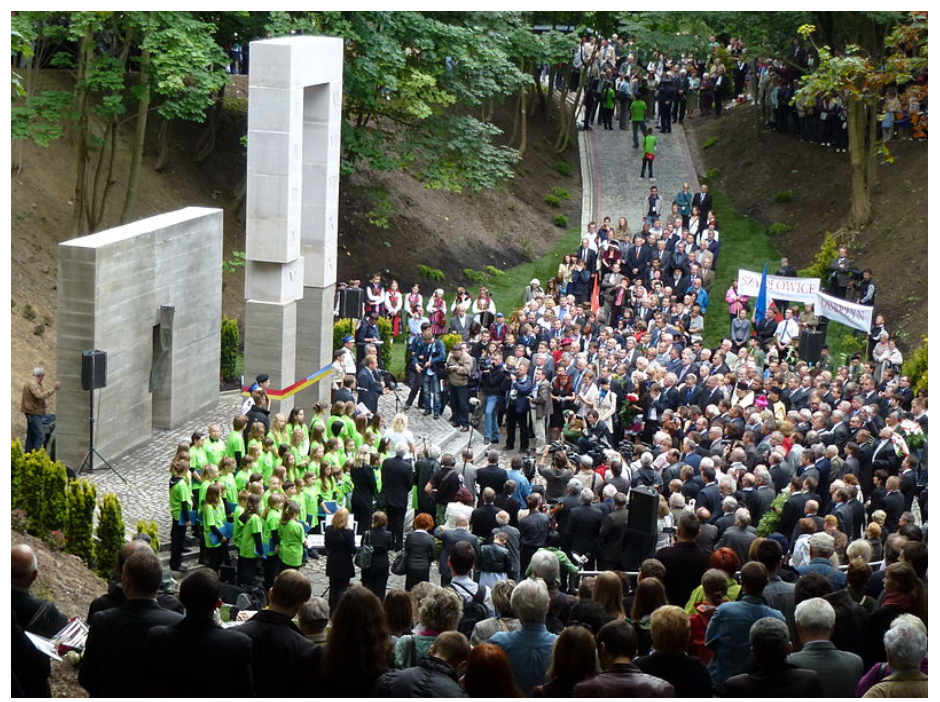

Figure 13. The Monument to those who had been shot in 1941to representatives of the Polish intelligentsia, Lviv

The Main directions of scientific research: pathological anatomy and experimental studies of tumors, in particular, lung cancer; pathophysiology of hormonal regulation, in particular, the study of the effect of adrenaline on the adrenal chromaffin tissue and kidney morphology; pathological anatomy of infectious diseases (dysentery, typhoid, paratyphoid), scleroma; pathological-anatomical casuistic - the study of aneurysms of the brain arteries, congenital bowel defects, pathology of the appendix, liver abscesses caused by ascarids, etc.; history of medical education and science development in Lviv.

Achievements: Four of Nowicki's pupils became professors, the author of about 90 scientific papers in Polish, German and French, among them a number of monographs, a pathological anatomy textbook in 3 volumes of "Anatomia Patologiczna", which contains a huge database of various pathologies illustrated 1200 drawings, executed under the personal guidance of Professor W. Nowicki.

\section{CONCLUSIONS}

Department of Pathological Anatomy and Forensic Medicine of Danylo Halytsky Lviv National Medical University celebrates its 120th anniversary, we bow our heads in honour of the distinguished scientists - founders, wonderful educators, and researchers - and continue to write about the history, traditions of high-quality education, the union of education, science 
and practice, international recognition, and continuous improvement of training of specialists in accordance with the requirements of modern society.

Today 22 scientific schools actively function and develop in University. Every Year Danylo Halytsky Lviv National Medical University Ranks Among Top 3 Medical Institutes in the Country. Web metrics (2019) gave it a Country Rank of 12 out of 320 Universities in Ukraine, a World Rank of 3551 out of 27219 Universities in the World, a Continental (Europe) Rank of 1107 out of 5833 Universities in Europe.

In 2009, when the medical university celebrated its $225^{\text {th }}$ anniversary since its foundation the Government of Ukraine launched a 5 Ukrainian Hryvnia Coin with the Seal, Name and Motto of the Medical University in the Honour and Respect of the Prestigious Institution.

Today Danylo Halytsky Lviv National Medical University combines 6 faculties, medical college, 78 departments (including 48 clinical departments), 14 academic buildings, 41 affiliated hospitals, University dental medical Centre for more than 2000 attendances during shift, teaching drugstore, botanical garden, CRL and Laboratory of industrial toxicology, Institute of clinical pathology, research centre for investigation of anticancer drugs, scientific library, 8 student hostels, sanatorium, student cafes and canteens, sports and health recovery camp "Medyk".

At 78 University departments, at the Institute of Clinical Pathology, in the Central Research Laboratory (CRL) and Laboratory of industrial toxicology are working 1211 scientists: 134 Doctor of Sciences and more than $620 \mathrm{PhD}$ degree holders, including 113 full professors, 369 associate professors, 50 senior tutors, 662 assistant professors, 17 researchers. Among them there are 23 Members, 7 Corresponding Members of Academy of Sciences, 13 Honored Workers of Science and Technology, 7 Honored Workers of Education, 19 Honored Doctors, 1 Honored Worker of Physical Culture and Sport, 9 Laureates of the State Prize of Ukraine in Science and Technology ${ }^{23,24}$.

\section{SUMMARY}

This article presents an overview of the professional, scientific and social working of a prominent Polish pathologist - professor Witold Nowicki. Professor W. Nowicki is rightly considered as one of the great clinical pathologist of the first half of XX century. He was apprentice of the founder and

${ }^{23}$ Zimenkovsky BS. Professors of Danylo Halytsky National Medical University of Lviv: 1784-2009. Lviv: Nautilus XXVIII, 2009. 452 p. [in Ukrainian]

${ }^{24}$ Danylo Halytsky National Medical University of Lviv: 2004. Lviv, Nautilus, 2004. [in Ukrainian] 
first head of the pathological anatomy department of John Casimir University of Lviv professor Andrzej Obrzut. He remained rich scientific heritage - more than 90 papers in Polish, German and French languages. Result of many years of work in institution of the pathological anatomy in cooperation with other teachers was fundamental three-volume textbook "Anatomia Patologiczna", which was illustrated by more than 1200 pictures, performed under personal management of professor W. Nowicki (Fig. 8, Ref. 23).

\section{REFERENCES}

1. Zerbino D.D. Vitold Novitsky is a prominent clinical pathologist of the first half of the twentieth century (on the 100th anniversary of his birth. Archive of Pathology. 1978, No. 10: 77-79 [in Russian]

2. Zerbino D.D., Volos L.I., Ivashchenko V.A. Professor Witold Nowicki - great clinical pathologist of first half of the XX century, Head of the Department of Pathological Anatomy (1919-1941) of the Medical Faculty of Lviv Jan Kazimierz University (dedicated to the $140^{\text {th }}$ anniversary of the birth). XXI Zjazd Polskiego Towarzystwa Patologów Lublin, 2628 września 2019 r. Streszczenia Abstracts. Pol J Pathol. 2019; 8-9. [in English]

3. Albert Z. Anatomia patologiczna we Lwowie w XVIII-XX wieku. F Arch Hist Filoz Med 2001; 56 (3): 229-251; Language : PL.

4. Shapiro I.Ya. Essays on the history of the Lviv Medical Institute. Lviv, LGMI 1959: 150-154 [foto] [in Russian]

5. Hahn W. Kronika Uniwersytetu Lwowskiego [Chronicle of Lvov University]. Lvov 1912; 2: 265, 349-350, 455-457. [in Polish]

6. Wielka ilustrowana encyklopedia powszechna. Krakow, 1938, Bd. 1-22.

7. Zwoździak W. Historia Wydziału Lekarskiego Uniwersytetu Lwowskiego [History of the Faculty of Medicine of the Lwów University]. Arch Hist Med (Warsz) 1965; 28: 57-85, 209-280, 309-336. [in Polish]

8. Nowicki W. Andrzej Obrzut. (Wspomnienie pośmiertne) [Andrzej Obrzut. (Obituary)]. Przegl Lek 1910; 49: 600. [in Polish]

9. Nowicki W. O skombinowanem zastosowaniu pośrednich sposobów w badaniu stolców tyfusowych, paratyfusowych i czerwonkowych [On combined appliance of indirect methods in examination of stools of typhus, paratyphus, and dysentery-infected patients]. Kraków. Reprint from Przegl Lek 1917; 8: 2. [in Polish]

10. Nowicki W. Ueber chronisch entstehendes Gasblaschenemphysem (Pneumatosis cystoides) [About chronic arising "gas bubble emphysema"]. Virchows Archiv fur pathologie Anatomie und Physiologie und fur klinsche Medizin 1909; 198: 143-182 
11. Nowicki W. Obrazy histologiczne twardzieli, szczególnie w jej okresie zejściowym [Histological pictures of scleroma, particularly at its end stage]. Pol Gaz Lek 1933; 12; 696-700. [in Polish]

12. Nowicki W. Rak - jako zagadnienie w nauce [Cancer as an issue in science]. Pol Gaz Lek 1939; 18: 1-3. [in Polish]

13. Nowicki W. Sprawa przyrostu raka płuc w świetle materjału sekcyjnego Instytutu Anatomji Patologicznej U. J. K. we Lwowie. [Report of increase in lung cancer cases in autopsy material of Institute of Pathological Anatomy UJK in Lvov]. Pol Gaz Lek 1931; 10: 99. [in Polish]

14. Nowicki W. Otwór górny klatki piersiowej w świetle badań anatomicznych i stosunek jego gruźlicy płuc pochodzenia szczytowego [Superior apertura of thorax in light of anatomical studies and its relation to apical pulmonary tuberculosis]. Pam Tow Lek 1914; 110: 1-67, 137-175, 259-283. [in Polish]

15. Nowicki W. Dalsze badania doświadczalne nad stosunkiem nadnercza do nerki [Further experimental studies on relation of suprarenal gland to kidney]. Lwowski Tyg Lek 1910; 5: 439-441. [in Polish]

16. Nowicki W. Anatomja patologiczna podręcznik do użytku studentów i lekarzy. Część ogólna [Pathological Anatomy: handbook for students and medical doctors. General Part]. Drukarnia Gubrynowicza i syna. Druk W.L. Anczyca i spółki Kraków 1928; 596. [in Polish]

17. Nowicki W. Anatomja patologiczna szczegółowa. Podręcznik do użytku studentów i lekarzy. Tom II [Systemic Pathological Anatomy. Handbook for students and medical doctors. Volume II]. Polska Akademia Umiejętności, Kraków 1936; 471. [in Polish]

18. Nowicki W, Franke U. W sprawie utworzenia Związku polskich towarzystw lekarskich i wydawania jego naukowego biuletynu [In case of establishment of Polish Medical Societies Association and editio of its scientific bulletin]. Pol Gaz Lek 1925; 4: 26-27. [in Polish]

19. Nowicki W. Morszyn [Morszyn]. Pol Gaz Lek 1932; 12: 814-815. [in Polish]

20. Nowicki W. Otwarcie Domu Zdrojowego w Morszynie - Zdroju [Openning of health-resort Centre in Morszyn Spa]. Pol Gaz Lek 1938; 17: 645-648. [in Polish]

21. Bonusiak W. Kto zabił profesorów lwowskich? [Who killed Lvovian Professors?] 1st ed. Krajowa Agencja Wydawnicza, Rzeszów 1989. [in Polish]

22. Zimenkovsky B.S. Professors of Danylo Halytsky National Medical University of Lviv: 1784-2009. Lviv : Nautilus XXVIII, 2009. 452 p. [in Ukrainian]

23. Danylo Halytsky National Medical University of Lviv : 2004. Lviv, Nautilus, 2004. [in Ukrainian] 


\section{Information about authors:}

Zerbino D. D.,

Academician of National Academy of Medical Sciences of Ukraine,

Professor of the Department of Pathological Anatomy and Forensic Medicine

Danylo Halytsky Lviv National Medical University 69, Pekarska str., Lviv, 79010, Ukraine

Volos L. I.,

Doctor of Medical Sciences, Professor of the Department of Pathological Anatomy and Forensic Medicine

Danylo Halytsky Lviv National Medical University 69, Pekarska str., Lviv, 79010, Ukraine 